\title{
In vitro protein digestibility of enzymatically pre-treated bean (Phaseolus vulgaris L.) flour using commercial protease and Bacillus sp. protease
}

\author{
Digestibilidade protéica in vitro de farinhas de feijão (Phaseolus vulgaris L.) \\ pré-tratadas com protease comercial e protease de Bacillus sp.
}

\author{
Disney Ribeiro DIAS ${ }^{1,2}$, Celeste Maria Patto de ABREU ${ }^{3}$, \\ Marialice Pinto Coelho SILVESTRE ${ }^{4}$, Rosane Freitas SCHWAN $5,1 \star$
}

\begin{abstract}
The common bean (Phaseolus vulgaris L.) is a staple food in the Brazilian diet and represents the major source of dietary protein and other micronutrients and minerals. Despite the considerable protein concentration in beans, the food is considered of low biological value when compared to animal proteins and other plant protein sources. To improve the availability of protein in beans, enzymatic treatments were performed in four cultivars (ON, OPNS, TAL and VC3). The approach was a completely randomized design with four replicates. We used a $4 \times 3$ factorial arrangement (four cultivars and three treatments: treatment 1-addition of commercial protease (Trypsin 250, Difco), treatment 2-addition of protease from Bacillus sp., and treatment 3:-control without enzyme addition). The enzyme: substrate ratio was 5\% w/w (amount of enzyme per total protein in bean flour). The approach was a completely randomized design with four replicates. A $4 \times 3$ factorial arrangement (four cultivars and three treatments, the same as those mentioned above) was used. The concentration of total protein ( $\mathrm{g} .100 \mathrm{~g}^{-1}$ of dry matter) in the samples ranged from 16.94 to $18.06 \%$, while the concentration of total phenolics was between 0.78 and $1.12 \%$ (g Eq. tannic acid. $100 \mathrm{~g}^{-1} \mathrm{dry}$ matter). The in vitro protein digestibility of enzymatically untreated bean flour (control) ranged from 47.30 to $56.17 \%$ based on the digestibility of casein. Concentrations of $\mathrm{P}, \mathrm{K}, \mathrm{Ca}, \mathrm{Mg}$, and $\mathrm{Zn}$ observed in the four cultivars tested were within the average values available in the literature. Treatment 2 with protease from Bacillus sp. induced decreases in the levels of $\mathrm{Cu}$ and $\mathrm{Mn}$. The average Fe content increased in all bean flour samples when treated with proteases, reaching a maximum increase of $102 \%$ in the TAL flour treated with protease from Bacillus sp. The digestibility of all beans tested was significantly increased $(\mathrm{p}<0.05)$ after the enzyme treatment. The greatest change was observed in the OPNS cultivar treated with protease from Bacillus sp., which increased its digestibility from $54.4 \%$ (control treatment) to $81.6 \%$.
\end{abstract}

Keywords: bean flour; enzymatic hydrolysis; alkaline protease.

\section{Resumo}

O feijão (Phaseolus vulgaris L.) é um alimento básico na refeição do brasileiro, constituindo uma das principais fontes proteicas da dieta, além de fornecer outros macronutrientes e minerais. Apesar da considerável concentração de proteínas no feijão, este alimento é considerado de baixo valor biológico, quando comparado a proteínas animais e a outras fontes proteicas vegetais. Visando melhorar a disponibilidade proteica do feijão, foram realizados tratamentos enzimáticos em quatro cultivares de feijão (ON; OPNS, TAL e VC3). O delineamento foi inteiramente casualizado, em fatorial $4 \times 3$ (quatro cultivares e três tratamentos: testemunha, sem protease; hidrolisado 1, adição de protease comercial (Trypsin 250, Difco); hidrolisado 2, adição de protease de Bacillus sp.) com 4 repetições. A relação enzima:substrato foi 5\% (m/m, considerando a quantidade de proteínas totais nas amostras de farinha). A concentração de proteínas totais (g. $100 \mathrm{~g}^{-1}$ de matéria seca) nas amostras variou de 16,94 a 18,06\%, enquanto a concentração de fenólicos totais esteve entre 0,78 e 1,12\% (g Eq. ácido tânico.100 $\mathrm{g}^{-1}$ de matéria seca). A digestibilidade protéica in vitro na farinha não tratada enzimaticamente (testemunha) variou entre 47,30 e 56,17\%, em relação à digestibilidade da caseína. As concentrações de $\mathrm{P}, \mathrm{K}, \mathrm{Ca}, \mathrm{Mg}, \mathrm{S}$ e Zn observadas nas quatro cultivares testadas se encontram dentro dos valores médios disponíveis na literatura. No tratamento com protease de Bacillus sp., houve diminuição nos teores de $\mathrm{Cu}$ e $\mathrm{Mn}$. O teor médio de Fe aumentou nas farinhas tratadas enzimaticamente, chegando ao incremento máximo de $102 \%$ para a farinha da TAL tratada com protease de Bacillus sp. A digestibilidade de todas as farinhas testadas aumentou significativamente $(\mathrm{p}<0,05)$ em função do tratamento enzimático. A maior variação foi observada na cultivar OPNS, cujos valores, respectivamente, para a testemunha e protease de Bacillus sp., foram 54,4 e 81,6\%.

Palavras-chave: farinha de feijão; hidrólise enzimática; protease alcalina.

\section{Introduction}

Legumes are rich in macro and micronutrients and are used by many people as a source of protein, carbohydrate, fiber, vitamins, and minerals. The common bean (Phaseolus vulgaris)

is an important dietary vegetable and is considered the main protein source in the diet of many Latin American countries, especially Brazil (FIALHO et al., 2006; MEJIA et al., 2005).

Recebido para publicação em 10/2/2008

Aceito para publicação em 26/9/2008 (003218)

Departamento de Ciência dos Alimentos, Programa de Pós-Graduação em Ciência dos Alimentos, Universidade Federal de Lavras - UFLA

2 Centro Universitário de Lavras - Unilavras. Rua Padre José Poggel, 506, CEP 37200-000, Centenário, Lavras - MG, Brasil

${ }^{3}$ Departamento de Química, Universidade Federal de Lavras - UFLA. C.P. 3037, CEP 37200-000, Lavras, MG, Brasil

${ }^{4}$ Departamento de Alimentos, Faculdade de Farmácia, Universidade Federal de Minas Gerais - UFMG. Av. Antonio Carlos, 6627, CEP 31270-901, Belo Horizonte - MG, Brasil

${ }_{5}^{5}$ Departamento de Biologia, Universidade Federal de Lavras - UFLA. C.P. 3037, CEP 37200-000, Lavras, MG, Brasi, e-mail: rschwan@ufla.br

${ }^{*}$ A quem a correspondência deve ser enviada 
The protein concentration of the common bean varies from 15 to $25 \%$, comprising up to $36 \%$ of the bean in some cultivars. The carbohydrate content varies from 40 to $60 \%$, mainly made up of starch (up to $45 \%$ of total carbohydrates), other polysaccharides (fibres), and to a lesser proportion, oligosaccharides (MESQUITA et al., 2007; SATHE, 2002; REHMAN; SALARIYA; ZAFAR, 2001).

The common bean is a good source of minerals; especially iron $(\mathrm{Fe})$, which is involved in several metabolic activities. It is associated with the porphyrin group to compose the heme, which is present in many molecules including hemoglobin, myoglobin, catalase, and other oxidorreductases, and which among other functions, are important for aerobic respiration (ANDREWS, 1999). The iron linked to the heme group and to iron-sulfur complexes is abundant in animal protein, while the iron unrelated to the heme group, inorganic iron, can be found in plant and animal tissues. Hemic iron is better absorbed by the body when compared to nonhemic iron (BEARD; DAWSON; PIÑERO, 1996; BIANCHI; SILVA; OLIVEIRA, 1992; CARPENTER; MAHONEY, 1992).

The required daily amount of Fe consumption is low. It ranges from $1.0 \mathrm{mg} \cdot \mathrm{kg}^{-1}$ for men and $1.3 \mathrm{mg} \cdot \mathrm{kg}^{-1}$ for women and youth, and its recommended dietary allowance is of $9 \mathrm{mg}$ for men and $16 \mathrm{mg}$ for women and youth (BEARD; DAWSON; PIÑERO, 1996; CARPENTER; MAHONEY, 1992). Meanwhile, according to the World Health Organization, iron deficiency anemia affects about $25 \%$ of the world population, mostly women and children (STOLTZFUS; MULLANY; BLACK, 2004).

The absorption of iron from legume sources (nonheme iron) is low when compared to hemic iron and appears to be compromised by the iron-protein and iron-polysaccharide interaction present in the common bean. The interaction of $\mathrm{Fe}$ with other molecules, such as phytates, oxalates, and phenolic compounds, considered antinutritional factors, also promotes the decrease in availability and consequent absorption of Fe (MOURA; CANNIATTI-BRAZACA, 2006; GUZMÁNMALDONADO; ACOSTA-GALLEGOS; PAREDES-LÓPEZ, 2000; LYNCH, 1997). These interactions are connected through an unclear mechanism with the beans' low protein digestibility and low availability of Fe. For this reason, the common bean is not a good source of protein and iron, making it a low biological value food when compared to animal and cereal proteins and other hemic iron sources (PIN; LAJOLO, 2003; COELHO; SGARBIERI, 1995; HUGHES et al., 1996).

Improving the biological value of common bean proteins has been the subject of several studies. The genetic improvement of cultivars that have higher protein digestibility and lower levels of antinutritional factors, including the pre-processing of beans by soaking and cooking, are some of the methods used to improve beans' nutritional value (MESQUITA et al., 2007; RIOS; ABREU; CORRÊA, 2003; WU et al., 1994).

The enzymatic hydrolysis of proteins can be a way to improve the biological value and functional properties of these molecules and has been previously used in the food industry (NIELSEN; OLSEN, 2002; CLEMENTE, 2000; ADLER-NISSEN, 1986).
Proteases have been used to modify proteins structures, as for instance in the hydrolysis of soybean proteins, solubilization of fish protein concentrates, meat softening, hydrolysis of milk casein, and changing cheese texture, thus enhancing the quality and nutritional value of the end products (NIELSEN; OLSEN, 2002; GODFREY, 1996; PEARCE, 1995).

In order to improve the in vitro protein digestibility of common beans, four cultivars were processed into flour, and the bean flour underwent two treatments: (i) prehydrolysis with a commercial protease (Trypsin 250, DIFCO), called hydrolysate 1 and (ii) prehydrolysis with protease obtained from Bacillus sp. UFLA $817 \mathrm{CF}$ to $60 \%\left(\mathrm{NH}_{4}\right)_{2} \mathrm{SO}_{4}$ saturation (DIAS et al., 2008), called hydrolysate 2 . The results were compared with those obtained in untreated flour by proteolytic hydrolysis (control).

\section{Materials and methods}

\subsection{Bean cultivars}

The varieties of beans used were Ouro Negro (black), OP-NS-331 (beige with brown strips), Talismã (beige with brown strips), and VC-3 (beige with few clear brown strips), all kindly provided by Prof. Magno Antonio Patto Ramalho (Department of Biology/Universidade Federal de Lavras, Lavras, Minas Gerais). The common beans flours were codified as ON (ouro negro), OPNS (OP-NS-331), TAL (Talismã), and VC3 (VC-3).

The beans were selected, cleaned, and dried at $40{ }^{\circ} \mathrm{C}$ for 24 hours, then ground in a Willye mill using a 30 mesh sieve. The beans were ground into two fractions: flour (consisting mainly cotyledon) and meal (the fraction retained in the milling and consisting mainly of bean husks and not used in this experiment). The bean flour obtained was packed and stored at $-20^{\circ} \mathrm{C}$ for further analysis.

\subsection{Enzyme hydrolysis of bean flour}

To obtain the protein hydrolysates from bean flour in the pre-hydrolysis stage, $20 \mathrm{~g}$ of samples were added to 80 $\mathrm{ml}$ of distilled water to facilitate contact between enzyme and substrate. The hydrolysis conditions for both powders of commercial protease (Trypsin 250, Difco) and protease from Bacillus sp. were as follows: $150 \mathrm{rpm}$, for 5 hours at $28^{\circ} \mathrm{C}$ and enzyme-substrate ratio of $5 \%(\mathrm{w} / \mathrm{w}$ - referring to the amount of protein per mass in each sample of bean flour). The $\mathrm{pH}$ of the bean flour solution varied according to the specificity of each enzyme. The $\mathrm{pH}$ value was adjusted to 7.0 with $0.01 \mathrm{~N} \mathrm{NaOH}$ in the commercial protease treatment, and to $\mathrm{pH} 9.0$ when Bacillus sp. protease was used. After hydrolysis, the samples of bean flour were frozen and dried.

\subsection{Analysis of bean flour}

The lyophilized hydrolyzed protein from the four bean varieties using either commercial protease or protease from Bacillus sp. as well as the non-hydrolysed bean meal (control), 
were all used for analyzing the protein, moisture, minerals, ash, in vitro protein digestibility, and total phenolic content.

The determination of total protein content was performed using the micro Kjeldahl method according to that described in AOAC (1995). The ash content was determined by the gravimetric method, based on the material's weight loss when heated at $550{ }^{\circ} \mathrm{C}$. The moisture of the flour was evaluated at $105^{\circ} \mathrm{C}$ (AOAC, 1995). The quantification of minerals was carried out according to Malavolta, Vitti and Oliveira (1989). The sample extracts were obtained by nitro-perchloric digestion. Sulphur and potassium content were determined by colorimetry. $\mathrm{Ca}$, $\mathrm{Mg}, \mathrm{Cu}, \mathrm{Fe}, \mathrm{Mn}$, and $\mathrm{Zn}$ content were determined by atomic absorption spectrophotometry, and $\mathrm{K}$ by flame photometry.

The determination of total phenolic content was carried out as described by Swain and Hillis (1959). Folin-Denis reagent and $\mathrm{Na}_{2} \mathrm{CO}_{3}$ saturated solution were prepared according to AOAC (1995). For extracting the phenolic compounds, the procedure proposed by Hagerman and Butler (1980) was used. The flour and hydrolysate samples were placed in a solution of methanol $80 \%(\mathrm{v} / \mathrm{v})$ in a water bath at $80{ }^{\circ} \mathrm{C}$ with reflux for 15 minutes. The supernatant was collected and evaporated, diluted with water and filtered for quantification. Tannic acid was used as a standard and the results were expressed as percentage of tannic acid equivalent ( $\mathrm{g}$ Eq. tannic acid $100 \mathrm{~g}^{-1}$ of matter).

The in vitro protein digestibility was determined according to the method of Akesson and Stahmann (1964). The samples (flour and hydrolysates with known nitrogen levels) were digested with pepsin and pancreatin at an optimum $\mathrm{pH}$ value. The reaction was stopped by the addition of $10 \%$ trichloroacetic acid solution. After centrifugation, the nitrogen content in the supernatant was determined. The digestibility of casein was taken as the standard and its value was set as $100 \%$. The values of the in vitro protein digestibility of flour and hydrolysates were corrected in relation to casein digestibility and the results were expressed in percentage on a dry basis.

For the comparison between flour and hydrolysates, we used a completely randomized design, with 4 replicates in a $4 \times 3$ factorial scheme (four varieties of beans, three treatments control and two enzymes). The data were analyzed using ANOVA and Tukey's test $(\mathrm{p}<0.05)$ using the Sisvar 5.0 software (FERREIRA, 2000).

\section{Results and discussion}

\subsection{Chemical composition of bean flour}

The total protein percentage in the untreated bean flour from the tested cultivars (ON, OPNS, TAL and VC3) ranged from 16.94 to $18.06 \mathrm{~g} .100 \mathrm{~g}^{-1}$, based on dry matter (Table 1). These values are consistent with those described for common beans in the literature (RIOS; ABREU; CORRÊA, 2003; SATHE, 2002).

The ON cultivar showed a higher percentage of protein (18.06\%) and ash (4.47\%). This cultivar also had the lowest total phenolic values (0.78) and the lowest humidity (6.08). There were no statistical differences in the ash content of the
OPNS, TAL, and VC3 cultivars. Concerning to total protein content, $\mathrm{ON}$ and TAL were not statistically different, and their protein content was higher than in cultivars VC3 and OPNS. The moisture of the samples ranged from 6.1 to $9.5 \%$ (Table 1).

The total phenolic content was between 0.78 and $1.12 \%$ equivalent of tannic acid $\left(\mathrm{g} .100 \mathrm{~g}^{-1}\right)$. Espinosa-Alonso et al. (2006), studying varieties of Mexican common beans, and Mesquita et al. (2007), analyzing beans cultivated in southern Minas Gerais, Brazil, found values of total phenolic content similar to the ones seen in this study and which are related with values previously described (MEJIA et al., 2005; MA; BLISS, 1978). The total amount of phenolics in the TAL cultivar (1.10\%) did not differ statistically from the highest value found for this parameter, seen in the OPNS cultivar (1.12\%). This cultivar had the smallest amount of total protein (16.94\%), statistically equivalent to the value found in cultivar VC3 (17.00\%).

The in vitro protein digestibility of enzymatically untreated bean flour varied depending on the cultivar, with the smallest value in the VC3 variety $(47.30 \%)$ and greatest value in the TAL cultivar $(56.17 \%)$. The digestibility can vary between 40 and $80 \%$, depending on the cultivar, cultivation conditions, and the pre-processing of beans (cooking, branching, hydration, irradiation, salt addition) (MECHI; CANIATTI-BRAZACA; ARTHUR, 2005; RIOS; ABREU; CORRÊA, 2003; GUZMÁNMALDONADO; ACOSTA-GALLEGOS; PAREDES-LÓPEZ, 2000; WU et al., 1994).

Several studies described the anti-nutritional effect of phenolic compounds on the biological quality of the beans' protein digestibility (GUZMAN-MALDONADO; PAREDESLOPEZ, 1999; CARVALHO; SGARBIERI, 1998; HUGHES et al., 1996; OH et al., 1980). From the results observed in the values of digestibility and total phenolics of the flour tested in this work, no negative correlation between these two parameters was seen. This was probably because the VC3 cultivar had both the lowest in vitro protein digestibility and concentration of total phenolics. Similar results were observed by Mesquita et al. (2007), which can be justified by the low phenolic:protein (w/w) ratio, as reported by Pin and Lajolo (2003). According to these authors, the decrease in digestibility occurs from the ratio of phenolic:protein on the order of 5:20 (w/w), or $5 \mathrm{~g}$ of phenolic for every $20 \mathrm{~g}$ of protein.

The maximum phenolic:protein ratio observed in the four analyzed cultivars was of approximately 1:17, in cultivar OPNS (Table 1), which may explain the non-interference in the phenolic values in the total protein digestibility found in this work.

\subsection{Protein hydrolysates obtained from bean flour}

There was no significant interaction at $5 \%$ for total protein and total phenolic content for the enzymatic treatment, using either commercial protease (Trypsin 250, DIFCO) or protease from Bacillus sp. with the bean flour obtained from the four different cultivars.

The values of $\mathrm{P}, \mathrm{K}, \mathrm{Ca}, \mathrm{Mg}, \mathrm{S}$ and $\mathrm{Zn}$ seemed to be stable for the four cultivars evaluated (ON, OPNS, TAL and VC3) 
(Table 2) in all three treatments (control without protease, hydrolysate 1, commercial protease and hydrolysate 2, protease from Bacillus sp.) The values found for these minerals, in the flour of the four evaluated bean cultivars, are similar to those available in the literature (USDA, 2007; MESQUITA et al., 2007; FRANCO, 2001). The concentrations of $\mathrm{Cu}$ and $\mathrm{Mn}$ remained close to the control when treated with commercial protease (hydrolysate 1), and decreased when the bean flour was treated with protease from Bacillus sp. (hydrolysate 2). This decline may have been due to the structure of the protease from Bacillus sp., which requires these metals as enzyme cofactors during catalysis (WANG et al., 2006; RAO et al., 1998).

The availability of Fe also varied according to the cultivar and enzymatic treatment used. The most striking results were observed in the TAL cultivar. When compared to the control, hydrolysate 1 showed an average increase of $66 \%$ while hydrolysate 2 increased by an average of $102 \%$. For the other cultivars, there was an increase of 19 and $30 \%$ respectively, in hydrolysates 1 and 2 for cultivar OPNS and 6 and 21\%, respectively, in hydrolysates 1 and 2 for cultivar VC3. This increase in Fe concentration may be related to the change in the Fe-protein interaction, as the protease generates conformational changes and decreases the size of the polypeptide chain due to its hydrolytic action. This results in the reduction of $\mathrm{Fe}$-protein interactions in the flour due to broken peptide links (NELSON; POTTER, 1980). These findings were similar to those reported

Table 1. Chemical and biochemical characteristics of the four bean cultivars (control)*.

\begin{tabular}{lccccc}
\hline $\begin{array}{c}\text { Beans } \\
\text { Flour }\end{array}$ & $\begin{array}{c}\text { Protein } \\
(\%)\end{array}$ & $\begin{array}{c}\text { Digestibility } \\
(\%)\end{array}$ & $\begin{array}{c}\text { Total Phenolics }^{2} \\
(\%)\end{array}$ & $\begin{array}{c}\text { Moisture } \\
(\%)\end{array}$ & $\begin{array}{c}\text { Ash } \\
(\%)\end{array}$ \\
\hline ON & $18.06^{\mathrm{a}}$ & $51.62^{\mathrm{ab}}$ & $0.78^{\mathrm{b}}$ & $6.08^{\mathrm{c}}$ & $4.47^{\mathrm{a}}$ \\
OPNS & $16.94^{\mathrm{b}}$ & $54.36^{\mathrm{ab}}$ & $1.12^{\mathrm{a}}$ & $8.70^{\mathrm{b}}$ & $3.77^{\mathrm{b}}$ \\
TAL & $18.04^{\mathrm{a}}$ & $56.17^{\mathrm{a}}$ & $1.10^{\mathrm{a}}$ & $9.35^{\mathrm{a}}$ & $3.82^{\mathrm{b}}$ \\
VC3 & $17.00^{\mathrm{b}}$ & $47.30^{\mathrm{b}}$ & $0.80^{\mathrm{b}}$ & $9.45^{\mathrm{a}}$ & $3.80^{\mathrm{b}}$ \\
\hline
\end{tabular}

${ }^{*}$ Average followed by a same letter did not differ statistically using Tukey test $(\mathrm{p}<0,05)$.

${ }^{1}$ Values corrected in relation to the case in digestibility, which is considered $100 \%$ digestible. ${ }^{2}$ In g of Eq. tannic acid. $100 \mathrm{~g}^{-1}$ of dry weight. Obs.: ON (Ouro Negro), OPNS (OP-NS-331), TAL (Talismã) and VC3 (VC-3). by Lombardi-Boccia, Santis and Lullo (1995) in samples of cooked beans. The availability of $\mathrm{Fe}$ in the treatments using the ON cultivar tended to be stable.

The in vitro protein digestibility of bean flour varied significantly $(\mathrm{p}<0.05)$ depending on the treatment (Figure 1$)$. Hydrolysates 1 and 2 showed higher digestibility than the untreated flour (control).

The flour obtained from cultivar OPNS showed the highest digestibility $(81.6 \%)$ when treated with the protease from Bacillus sp., an increase of about $50 \%$ when compared to the untreated flour (54.4\%) of the same cultivar. On the other hand, the treatment with commercial enzyme (hydrolysate 1) produced the best result for the ON cultivar (74.38\%), increasing the digestibility by about $44 \%$, when compared to the control (51.6\%). For this cultivar, the protease from Bacillus sp. (hydrolysate 2 ) increased the digestibility by $27.3 \%$ when compared to the control (65.7 and 51.6\%, respectively).

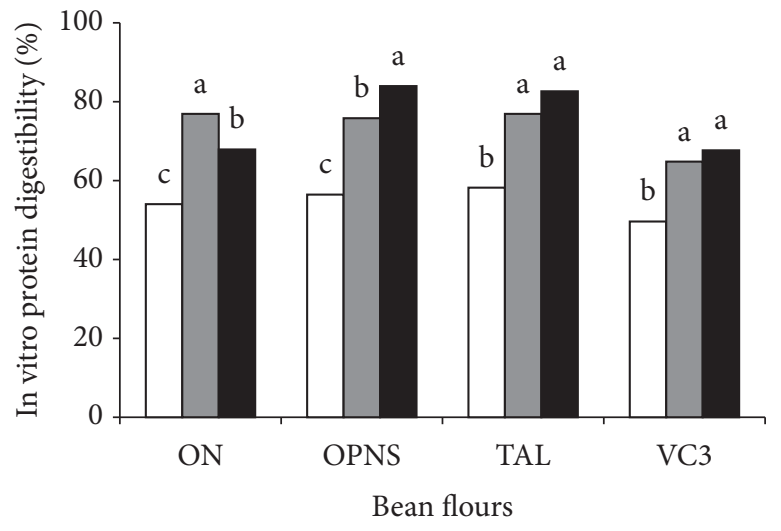

$\square$ Control $\square$ Tryps in 250 DIFCO Bacillus sp protease

Figure 1. In vitro protein digestibility of bean flours after enzymatic treatment. Different letters indicate statistically difference by the Tukey test at 5\%. Obs.: ON (Ouro Negro), OPNS (OP-NS-331), TAL (Talismã) and VC3 (VC-3).

Table 2. Mineral content in the four bean cultivars analyzed with different enzyme treatments*.

\begin{tabular}{|c|c|c|c|c|c|c|c|c|c|c|c|c|c|}
\hline & & \multicolumn{4}{|c|}{$\begin{array}{c}\text { Control } \\
\text { (without protease) }\end{array}$} & \multicolumn{4}{|c|}{$\begin{array}{c}\text { Hydrolysate } 1 \\
\text { (Trypsin 250, DIFCO) }\end{array}$} & \multicolumn{4}{|c|}{$\begin{array}{c}\text { Hydrolysate } 2 \\
\text { (protease from Bacillus sp.) }\end{array}$} \\
\hline & & $\mathrm{ON}$ & OPNS & TAL & VC3 & $\mathrm{ON}$ & OPNS & TAL & VC3 & $\mathrm{ON}$ & OPNS & TAL & $\mathrm{VC} 3$ \\
\hline $\mathrm{N}$ & g. $100 \mathrm{~g}^{-1}$ & 2.74 & 2.49 & 2.65 & 2.47 & 2.71 & 2.45 & 2.61 & 2.42 & 2.70 & 2.47 & 2.59 & 2.50 \\
\hline $\mathrm{P}$ & & 0.41 & 0.33 & 0.35 & 0.38 & 0.41 & 0.40 & 0.35 & 0.34 & 0.34 & 0.43 & 0.40 & 0.37 \\
\hline $\mathrm{K}$ & & 1.54 & 1.43 & 1.38 & 1.29 & 1.46 & 1.45 & 1.38 & 1.31 & 1.25 & 1.42 & 1.38 & 1.32 \\
\hline $\mathrm{Ca}$ & & 0.03 & 0.01 & 0.03 & 0.05 & 0.02 & 0.03 & 0.05 & 0.05 & 0.02 & 0.05 & 0.04 & 0.04 \\
\hline $\mathrm{Mg}$ & & 0.16 & 0.19 & 0.19 & 0.17 & 0.18 & 0.20 & 0.19 & 0.20 & 0.13 & 0.19 & 0.18 & 0.17 \\
\hline $\mathrm{S}$ & & 0.23 & 0.22 & 0.25 & 0.21 & 0.26 & 0.24 & 0.25 & 0.23 & 0.16 & 0.20 & 0.20 & 0.19 \\
\hline $\mathrm{Cu}$ & $\mathrm{mg} .100 \mathrm{~g}^{-1}$ & 1.25 & 0.90 & 1.30 & 1.23 & 1.31 & 1.01 & 1.27 & 1.26 & 0.82 & 0.74 & 1.03 & 0.84 \\
\hline $\mathrm{Mn}$ & & 1.48 & 1.30 & 1.61 & 1.24 & 1.60 & 1.33 & 1.61 & 1.33 & 0.51 & 0.74 & 1.04 & 0.64 \\
\hline $\mathrm{Zn}$ & & 4.00 & 3.71 & 3.71 & 3.44 & 3.95 & 3.91 & 3.71 & 3.49 & 3.70 & 3.80 & 3.72 & 3.52 \\
\hline $\mathrm{Fe}$ & & 2.04 & 0.95 & 1.04 & 0.92 & 2.10 & 1.13 & 1.73 & 0.98 & 2.08 & 1.24 & 2.10 & 1.12 \\
\hline
\end{tabular}

${ }^{\star}$ Data are express based on dry weight. Obs.: ON (Ouro Negro), OPNS (OP-NS-331), TAL (Talismã) and VC3 (VC-3). 
There were no significant differences between the treatments with commercial protease and protease from Bacillus sp. for the TAL and VC3 cultivars, although the use of enzyme led to the greatest value for both flours (80.3 and $65.8 \%$, respectively) (Figure 1).

The increase in the digestibility values improved the nutritional quality of the bean proteins by favoring hydrolysis and the absorption of amino acids and short chain peptides, which is essential to animal metabolism (PIRES et al., 2006; BLANCO; BRESSANI, 1991). These results can be used to apply bean flour to food supplementation, such as protein hydrolysate as well as special diets in order to improve the absorption of oligopeptides in some human intestinal diseases (CLEMENTE, 2000; CORDLE, 1994; FROKJAER, 1994).

The TAL and VC3 cultivars did not show any statistical differences of protein digestibility between both enzymatic treatments. For the ON cultivar, the best results were reached using the commercial protease, while for the OPNS cultivar a better result was achieved using the protease produced by our Bacillus sp strain. In general, for all the cultivars, the use of protease improved digestibility in relation to the control.

\section{Conclusions}

The enzymatically treated cultivars showed a significant increase in protein digestibility, total phenolic content, moisture, and ash when compared to the untreated flour. There was a tendency toward decreased concentrations of $\mathrm{Cu}$ and $\mathrm{Mn}$ in all flour samples treated with protease from Bacillus $\mathrm{sp}$ (hydrolysate 2). The availability of Fe increased in hydrolysates 1 (protease commercial) and 2 (protease from Bacillus $\mathrm{sp}$ ) for the OPNS, TAL, and VC3 cultivars. Meanwhile, the highest increase in Fe availability (102\%) was observed in hydrolysate 2 (protease from Bacillus sp) for the TAL cultivar. The in vitro protein digestibility was significantly improved with the enzyme treatment. For the ON cultivar, the best result (a 44\% increase) was obtained in hydrolysate 1 , using commercial protease. The highest increase in digestibility, however, was observed in the flour obtained from the OPNS cultivar treated with protease from Bacillus sp (hydrolysate 2), showing an increase of $50 \%$ when compared to the control digestibility. The enzyme treatment, regardless of the origin of the enzyme, improved the digestibility of the four bean varieties.

\section{Acknowledgements}

The authors wish to thank FAPEMIG and CNPq for financial support. D. R. Dias expresses his gratitude to UFLA and UNILAVRAS for the opportunity to take courses towards his PhD. The authors are grateful to Prof. Dr. Magno A. P. Ramalho for donating the common bean cultivars.

\section{References}

ADLER-NISSEN, J. Enzymic hydrolysis of food proteins. London: Elsevier Applied Science, 1986. 427 p.

AKESSON, W. R.; STAHMANN, M. A. A pepsin pancreatin digest index of protein quality evaluation. Journal of Nutrition, v. 83, n. 2, p. 257-261, 1964.
ANDREWS, N. C. Disorders of iron metabolism. New England Journal of Medicine, v. 341, n. 26, p. 1986-1995, 1999.

ASSOCIATION OF OFFICIAL ANALYTICAL CHEMISTS - AOAC. Official methods of analysis of AOAC international. $16 \mathrm{ed}$. Arlington, 1995.

BEARD, J. L.; DAWSON, H.; PIÑERO, D. J. Iron metabolism: a comprehensive review. Nutrition Reviews, v. 54, n. 10, p. 295-317, 1996.

BIANCHI, M. L. P.; SILVA, H. C.; OLIVEIRA, J. E. D. de. Considerações sobre a biodisponibilidade do ferro dos alimentos. Archivos Latinoamericanos de Nutrición, v. 42, n. 2, p. 94-100, 1992.

BLANCO, A.; BRESSANI, R. Biodisponibilidad de aminoácidos en el frijol (Phaseolus vulgaris). Archivos Latinoamericanos de Nutrición, v. 41, n. 1, p. 38-51, 1991.

CARPENTER, C. E.; MAHONEY, A. Contributions of heme and nonheme iron to human nutrition. Critical Reviews in Food Science and Nutrition, v. 31, n. 4, p. 333-367, 1992.

CARVALHO, M. R.; SGARBIERI, V. C. Relative importance of phytohemagglutinin (lectin) and trypsin-chymotrypsin inhibitor on bean (Phaseolus vulgaris L) protein absorption and utilization by the rat. Journal of Nutritional Science and Vitaminology, v. 44, n. 5, p. 685-696, 1998.

CLEMENTE, A. Enzymatic protein hydrolysates in human nutrition. Trends in Food Science and Technology, v. 11, n. 7, p. 254-262, 2000.

COELHO, R. G.; SGARBIERI, V. C. Nutritional evaluation of bean (Phaseolus vulgaris) protein: In vivo versus in vitro procedure. Journal of Food Biochemistry, v. 18, n. 5, p. 297-309, 1995.

CORDLE, C. T. Control of food allergies using protein hydrolysates. Food Technology, v. 48, n. 10, p. 72-76, 1994.

DIAS, D. R. et al. Alkaline protease from Bacillus sp. isolated from coffee bean grown on cheese whey. World Journal of Microbiology and Biotechnology, v. 24, n. 10, p. 2027-2034, 2008.

ESPINOSA-ALONSO, L. G. et al. Polyphenols in wild and weedy mexican common beans (Phaseolus vulgaris L.). Journal of Agricultural and Food Chemistry, v. 54, n. 12, p. 4436-4444, 2006.

FERREIRA, D. F. Análises estatísticas por meio do Sisvar para Windows versão 4.0. In: REUNIÃO ANUAL DA REGIÃO BRASILEIRA DA SOCIEDADE INTERNACIONAL DE BIOMETRIA, 45, 2000, São Carlos. Anais... São Carlos: UFSCar, 2000. p. 255-258.

FIALHO, L. S. et al. Biochemical composition and indigestible oligosaccharides in Phaseolus vulgaris L. seeds. Plant Foods for Human Nutrition, v. 61, n. 2, p. 87-89, 2006.

FRANCO, G. Tabela de composição química dos alimentos. 9 ed. São Paulo: Atheneu, 2001. 324 p.

FROKJAER, S. Use of hydrolysates for protein supplementation. Food Technology, v. 48, n. 10, p. 86-88, 1994.

GODFREY, T. Protein modification. In: GODFREY, T.; WEST, S. (Eds.). Industrial enzimology. 2 ed. Great Britain: Macmillan, 1996. Cap. 2.18.

GUZMÁN-MALDONADO, S. H.; ACOSTA-GALLEGOS, J.; PAREDES-LÓPEZ, O. Protein and mineral content of a novel collection of wild and weedy common bean (Phaseolus vulgaris L). Journal of the Science of Food and Agriculture, v. 80, n. 13, p. 1874-1881, 2000.

GUZMAN-MALDONADO, S.H.; PAREDES-LOPEZ, O. Biotechnology for the improvement of nutritional quality of food crop plants. In: 
PAREDES-LOPEZ, O. (Ed.). Molecular biotechnology for plant food production. Lancaster: Technomic, 1999. p. 590-591.

HAGERMAN, A. E.; BUTLER, L. G. Condensed tannin purification and characterization of tannin associated proteins. Journal of Agricultural and Food Chemistry, v. 28, n. 4, p. 947-952, 1980.

HUGHES, J. S. et al. Effects of dietary fiber and tannins on protein utilization in dry beans (Phaseolus vulgaris). Food Research International, v. 29, n. 3-4, p. 331-338, Apr.-May 1996.

LOMBARDI-BOCCIA, G.; SANTIS, N.; LULLO, G. Impact of processing on Fe dialysability from bean (Phaseolus vulgaris L.). Food Chemistry, v. 53, n. 2, p. 191-195, 1995.

LYNCH, S. R. Interaction of iron with other nutrients. Nutrition Reviews, v. 55, n. 4, p. 102-110, 1997.

MA, Y.; BLISS, F. A. Tannin content and inheritance in common bean. Crop Science, v. 18, n. 2, p. 201-204, 1978.

MALAVOLTA, E.; VITTI, G. C.; OLIVEIRA, S. A. Avaliação de estado nutricional das plantas. 2 ed. Piracicaba: Potafos, 1989. 201 p.

MECHI, R.; CANIATTI-BRAZACA, S. G.; ARTHUR, V. Avaliação química, nutricional e fatores antinutricionais do feijão preto (Phaseolus vulgaris L.) irradiado. Ciência e Tecnologia de Alimentos, v. 25, n. 1, p. 109-114, 2005.

MEJIA, E. G. et al. Tannins, trypsin inhibitors and lectin cytotoxicity in tepary (Phaseolus acutifolius) and common (Phaseolus vulgaris) beans. Plant Foods for Human Nutrition, v. 60, n. 4, p. 137-145, 2005.

MESQUITA, F. R. et al. Linhagens de feijão (Phaseolus vulgaris L.): composição química e digestibilidade protéica. Ciência e Agrotecnologia, v. 31, n. 4, p. 1114-1121, 2007.

MOURA, N. C.; CANNIATTI-BRAZACA, S. G. Avaliação da disponibilidade de ferro de feijão comum (Phaseolus vulgaris L.) em comparação com carne bovina. Ciência e Tecnologia dos Alimentos, v. 26, n. 2, p. 270-276, 2006.

NELSON, K. J.; POTTER, N. N. Iron availability from wheat gluten, soy isolate, and casein complexes. Journal of Food Science, v. 45, n. 1, p. 52-56, 1980.

NIELSEN, P. M.; OLSEN, H. S. Enzymic modification of food protein. In: WHITEHURST, R. J.; LAW, B. A.(Eds.). Enzymes in food technology. Sheffield: Sheffield Academic Press, 2002. Cap. 6, p. 109-143.
$\mathrm{OH}, \mathrm{H}$. I. et al. Hydrophobic interaction in tannin-protein complexes. Journal of Agricultural and Food Chemistry, v. 28, n. 2, p. 394398, 1980.

PEARCE, R. J. Food functionality success or failure for dairy based ingredients. Australian Journal of Dairy Technology, v. 50, n. 1, p. 15-23, 1995.

PIRES, C. V. et al. Qualidade nutricional e escore químico de aminoácidos de diferentes fontes protéicas. Ciência e Tecnologia dos Alimentos, v. 26, n. 1, p. 179-187, 2006.

RAO, M. B. et al. Molecular and biotechnological aspects of microbial proteases. Microbiology Molecular Biology Reviews, v. 62, n. 3, p. 597-635, 1998.

REHMAN, Z.; SALARIYA, A. M.; ZAFAR, S. I. Effect of processing on available carbohydrate content and starch digestibility of kidney beans (Phaseolus vulgaris L.). Food Chemistry, v. 73, n. 3, p. 351-355, 2001.

RIOS, A. O.; ABREU, C. M. P.; CORRÊA, A. D. Efeito da estocagem e das condições de colheita sobre algumas propriedades físicas, químicas e nutricionais de três cultivares de feijão (Phaseolus vulgaris L.). Ciência e Tecnologia de Alimentos, v. 23, n. 1, p. 39-45, 2003.

SATHE, A. K. Dry bean protein functionality. Critical Reviews in Biotechnology, v. 22, n. 2, p. 175-223, 2002.

STOLTZFUS, R. J.; MULLANY, L.; BLACK, R. E. Iron deficiency anaemia. In: EZZATI, M. et al. (Eds.). Comparative quantification of health risks: global and regional burden of disease attribution to selected major risk factors. Geneve: WHO, 2004. p. 163-210. Disponível em: <http://www.who.int/publications/cra/chapters/ volume1/0163-0210.pdf>. Acesso em: 20 Dezembro 2007.

SWAIN, T.; HILLIS, W. T. The phenolic constituents of Prunnus domestica. Journal of the Science of Food and Agriculture, v. 10, n. 2, p. 135-144, 1959.

USDA. National nutrient database for standard reference. Disponível em: <http://www.nal.usda.gov/fnic/foodcomp/search/>. Acesso em: 23 Novembro 2007.

WANG, S. L. et al. A solvent stable metalloprotease produced by Bacillus sp. TKU004 and its application in the deproteinization of squid pen for $\beta$-chitin preparation. Enzyme and Microbial Technology, v. 39, n. 4 , p. 724-731, 2006.

$\mathrm{WU}, \mathrm{W}$. et al. Thermal effects onin vitro protein quality of red kidney bean (Phaseolus vulgaris L.). Journal of Food Science, v. 59, n. 6, p. 1187-1191, 1994. 